\title{
Ostre rozsiane zapalenie mózgu i rdzenia kręgowego u dzieci jako następstwo jałowego zapalenia opon mózgowo-rdzeniowych - opis dwóch przypadków
}

\section{Acute disseminated encephalomyelitis in children as the result of aseptic meningitis - a report of two cases}

Violetta Gołąbek', Teresa Woźniakowska-Gęsicka', Doroła Sokołowska²

${ }^{1}$ III Klinika Pediatrii, Instyłut - Centrum Zdrowia Matki Polki w Łodzi

2Klinika Neurologii Dziecięcej, Instytut - Centrum Zdrowia Matki Polki w Łodzi

Neurologia i Neurochirurgia Polska 2011; 45, 2: 180-187

\section{Streszczenie}

Ostre rozsiane zapalenie mózgu i rdzenia kręgowego (acute disseminated encephalomyelitis - ADEM) charakteryzuje się odczynem zapalnym i demielinizacją w obrębie ośrodkowego układu nerwowego, które są następstwem chorób zakaźnych lub szczepień. Występuje bardzo rzadko, częściej u dzieci niż u dorosłych, zwykle kończy się pełnym wyzdrowieniem, ale może prowadzić do zgonu lub powodować odległe następstwa. Diagnoza choroby jest trudna i wymaga głównie różnicowania ze stwardnieniem rozsianym; najbardziej pomocne dla rozpoznania jest badanie za pomocą rezonansu magnetycznego. W ostrym okresie choroby postępowanie z wyboru stanowi steroidoterapia. W pracy przedstawiono dwa przypadki ADEM (u 6-letniego chłopca i 5-letniej dziewczynki) o niejasnej etiologii, będące następstwem jałowego zapalenia opon mózgowo-rdzeniowych.

Słowa kluczowe: ostre rozsiane zapalenie mózgu i rdzenia kręgowego, jałowe zapalenie opon mózgowo-rdzeniowych, stwardnienie rozsiane, dzieci.

\section{Wstęp}

Ostre rozsiane zapalenie mózgu i rdzenia (acute disseminated encephalomyelitis - ADEM) jest chorobą za-

\begin{abstract}
Acute disseminated encephalomyelitis (ADEM) is an inflammation of the spinal cord and brain. Diagnosis of ADEM, due to its rare occurrence and lack of definite laboratory indices, is difficult and is never totally certain. The clinical criterion required for the diagnosis is presence of acute symptoms from the brain and/or spine with fever, occurring after viral or bacterial infection, vaccination or serum administration. Differentiation between ADEM and acute multiple sclerosis in children is difficult, and diagnosis of ADEM may only be confirmed after years of observation, especially as multiple sclerosis is more common than ADEM. The most useful tool in differentiation between the two diseases is MRI. The aim of the study was to present two cases of ADEM with unknown aetiology after aseptic meningitis in children.
\end{abstract}

Key words: acute disseminated encephalomyelitis, aseptic meningitis, multiple sclerosis, children.

palną, przebiegającą zwykle jednofazowo, charakteryzującą się odczynem zapalnym i demielinizacją w ośrodkowym układzie nerwowym (OUN), z tendencją do okołożylnej lokalizacji zmian $[1,2]$. 
Etiologia choroby jest niejasna. Wiadomo, że ADEM występuje często w związku czasowym i prawdopodobnie przyczynowym z zakażeniami wirusowymi lub bakteryjnymi, szczepieniami ochronnymi, niekiedy po podaniu surowicy przeciwtężcowej lub po ukąszeniu przez owady [3]. Występuje rzadziej niż stwardnienie rozsiane (SR), częściej dotyka dzieci niż osoby dorosłe. Ostre rozsiane zapalenie mózgu i rdzenia rozpoznaje się na podstawie charakterystycznych zmian w OUN, widocznych w badaniu przy użyciu magnetycznego rezonansu jądrowego (RM). Zmiany demielinizacyjne w ADEM mogą dotyczyć istoty szarej półkul mózgu, ale przede wszystkim podkorowej istoty białej, zwojów podstawnych, międzymózgowia, pnia mózgu, móżdżku i rdzenia kręgowego [4,5]. W leczeniu najbardziej skuteczne okazały się kortykosteroidy, których podawanie zwykle prowadzi do pełnego wyzdrowienia $[6,7]$. Leczenie immunoglobulinami rezerwuje się dla pacjentów niereagujących na kortykosteroidy [8]. W przypadkach o najcięższym przebiegu stosowana jest plazmafereza [9]. W pracy przedstawiono dwa przypadki ADEM o nieustalonej etiologii u dzieci.

\section{Opisy przypadków}

\section{Przypadek 1.}

Sześcioletni chłopiec został przyjęty do kliniki z powodu zaburzeń świadomości, ataksji i zaburzeń widzenia. Wcześniej hospitalizowany w szpitalu powiatowym, gdzie rozpoznano zapalenie opon mózgowo-rdzeniowych (ZOMR). Choroba dziecka rozpoczęła się 3 tygodnie wcześniej gorączką powyżej $39^{\circ} \mathrm{C}$, wymiotami, bólem głowy i brzucha; w badaniach laboratoryjnych obserwowano leukocytozę (30 tys. $/ \mu \mathrm{l}$ ), prawidłowe stężenie CRP. Pomimo prowadzonej antybiotykoterapii stan pacjenta się pogorszył. W 6. dobie leczenia nasiliły się wymioty, chłopiec nadal gorączkował, skarżył się na bóle głowy, wystąpiły objawy oponowe. Badanie płynu mózgowo-rdzeniowego (PMR) wykazało nieswoiste zmiany zapalne (pleocytoza 34 kom./ $\mu$ l, komórki wielojądrzaste $64 \%$, komórki jednojądrzaste $36 \%$, stężenie białka $30 \mathrm{mg} / \mathrm{dl}$, stężenie glikemii $55 \mathrm{mg} / \mathrm{dl}$ ). Rozpoznano aseptyczne ZOMR, zastosowano typowe leczenie (ceftriakson, mannitol, deksametazon). Po 4 dobach leczenia uzyskano poprawę stanu ogólnego oraz ustąpienie objawów oponowych, jednakże w 10. dobie stan chłopca ponownie uległ pogorszeniu, powróciła gorączka, obserwowano nasilenie zaburzeń widzenia i równowagi oraz nadmierną senność. W tym stanie pacjent został przeniesiony do Instytutu - Centrum Zdrowia Matki Polki (ICZMP) w Łodzi. Przy przyjęciu chłopiec był przytomny, w logicznym kontakcie. W badaniu przedmiotowym z odchyleń od normy stwierdzono objawy oponowe, obustronny objaw Babińskiego i wygórowane odruchy głębokie. W badaniu okulistycznym zaobserwowano szerokie, okragge źrenice, bez pośredniej ani bezpośredniej reakcji na światło; chłopiec zgłaszał całkowity brak widzenia. Wykonano RM mózgowia, w którym wykazano obecność nieostro odgraniczonych obszarów hipointensywnych w obrazach Tl-zależnych oraz hiperintensywnych $\mathrm{w}$ obrazach T2-zależnych i sekwencjach FLAIR w obrębie głowy jądra ogoniastego i przedniej części jądra soczewkowatego po stronie prawej, w obrębie konara mózgu i tylnej części wzgórza po stronie lewej. Obserwowane zmiany nie ulegały wzmocnieniu po podaniu środka kontrastowego (ryc. 1.). W EEG wykonanym w stanie czuwania otrzymano zapis z dominacją fal theta $5-7 \mathrm{~Hz}$ o amplitudzie do $70 \mu \mathrm{V}$, bez reakcji zatrzymania i bez wpływu fotostymulacji na zapis. Badania biochemiczne nie wykazywały odchyleń. W obrazie morfologicznym krwi obwodowej stwierdzano leukocytozę (18 tys./ $\mu \mathrm{l}) \mathrm{z}$ odmłodzeniem w leukogramie, stężenie CRP wynosiło $0,26 \mathrm{mg} / \mathrm{dl}$. Badania serologiczne: przeciwciała w klasie IgM w kierunku zakażenia Mycoplasma pneumoniae, adenowirusem, HSV-1 i HSV-2 wypadły negatywnie, stwierdzono wysokie miano przeciwciał klasy IgG przeciwko HSV-1 i HSV-2 w teście oceniającym łącznie te dwa wirusy. Na podstawie całości obrazu klinicznego (wywiadu, badania przedmiotowego i badań dodatkowych) rozpoznano ADEM. Zastosowano leczenie metyloprednizolonem podawanym dożylnie w dawce $400 \mathrm{mg} /$ $\mathrm{m}^{2}$ przez 5 dni, uzyskując poprawę stanu ogólnego pacjenta. Leczenie kontynuowano, stosując deksametazon w dawce $0,4 \mathrm{mg} / \mathrm{kg}$ m.c./dobę przez kolejne $5 \mathrm{dni}$, a następnie prednizon w dawce $1 \mathrm{mg} / \mathrm{kg}$ m.c./ dobę. Po 12 dniach leczenia chłopca wypisano do domu w stanie znacznej poprawy. W dniu wypisu chłopiec chodził samodzielnie na nieco poszerzonej podstawie, odruchy głębokie były trochę żywsze po stronie lewej, odruchy patologiczne nieobecne, stwierdzono nieznaczne upośledzenie widzenia w postaci osłabienia ostrości wzroku (ostrość oka lewego oceniono na 3/5), źrenice reagowały na światło, badanie okulistyczne wykazało nieco bledszą tarczę nerwu II po lewej. W kontrolnym badaniu RM głowy wykonanym po 5 miesiącach obserwa- 


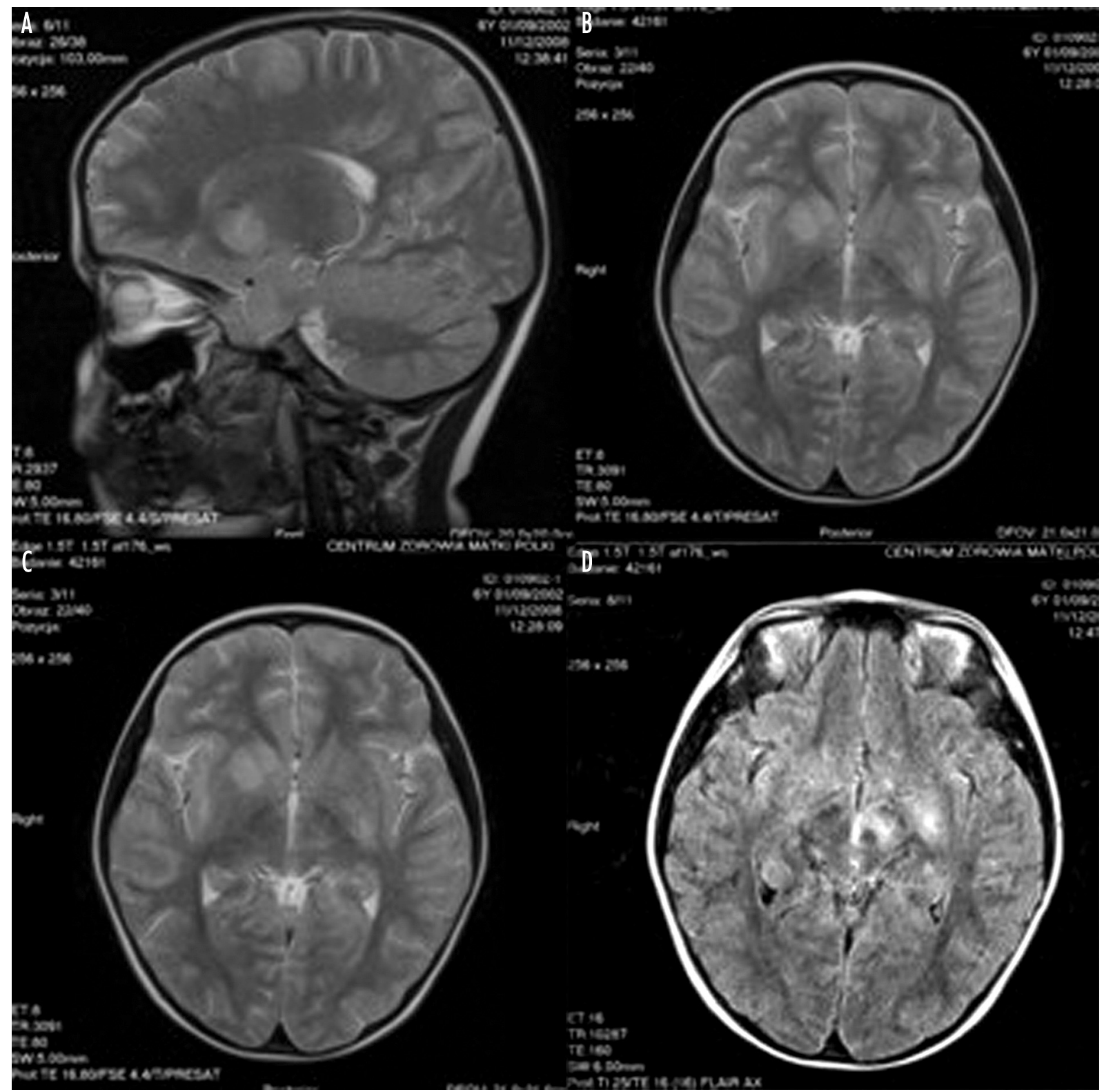

Ryc. 1. Rezonans magnetyczny mózgu chłopca (przypadek 1.) - ogniska hiperintensywne w sekwencij T2-zależnej w jaddrze ogoniastym po stronie prawej, w projekcii strzałkowej (A) i poprzecznej (C); w tylnej części wzgórza po stronie lewej - projekcja poprzeczna (B); w podkorowej istocie białej po stronie lewej w sekwencii FLAIR, projekcja poprzeczna (D)

Fig. 1. Brain MRI of the boy (case 1) - hyperintense lesions in T2-weighted images over anterior part of lenticular nucleus on the right side, sagittal image (A), axial image (C); in posterior thalamus on the left side - axial image (B); hyperintense lesions on FLAIR sequence in subcortical white matter on the left side - axial image (D)

cji wykazano całkowite ustapienie zmian patologicznych w mózgowiu.

\section{Przypadek 2.}

Czteroletnia dziewczynka, dotychczas zdrowa, została przyjęta do kliniki z powodu utrzymujących się od 3 tygodni stanów gorączkowych do $40^{\circ} \mathrm{C}$, apatii, senności i bólów głowy. W badaniach dodatkowych wykonanych ambulatoryjnie obserwowano leukocytozę i leukocyturię. Przy przyjęciu stan dziecka był dość dobry. Badaniem fizykalnym z odchyleń stwierdzano lekko wzdęty, tkliwy brzuch. Badania dodatkowe wykazały leukocytozę ( 26 tys. $/ \mu \mathrm{l})$, natomiast pozostałe bada- 


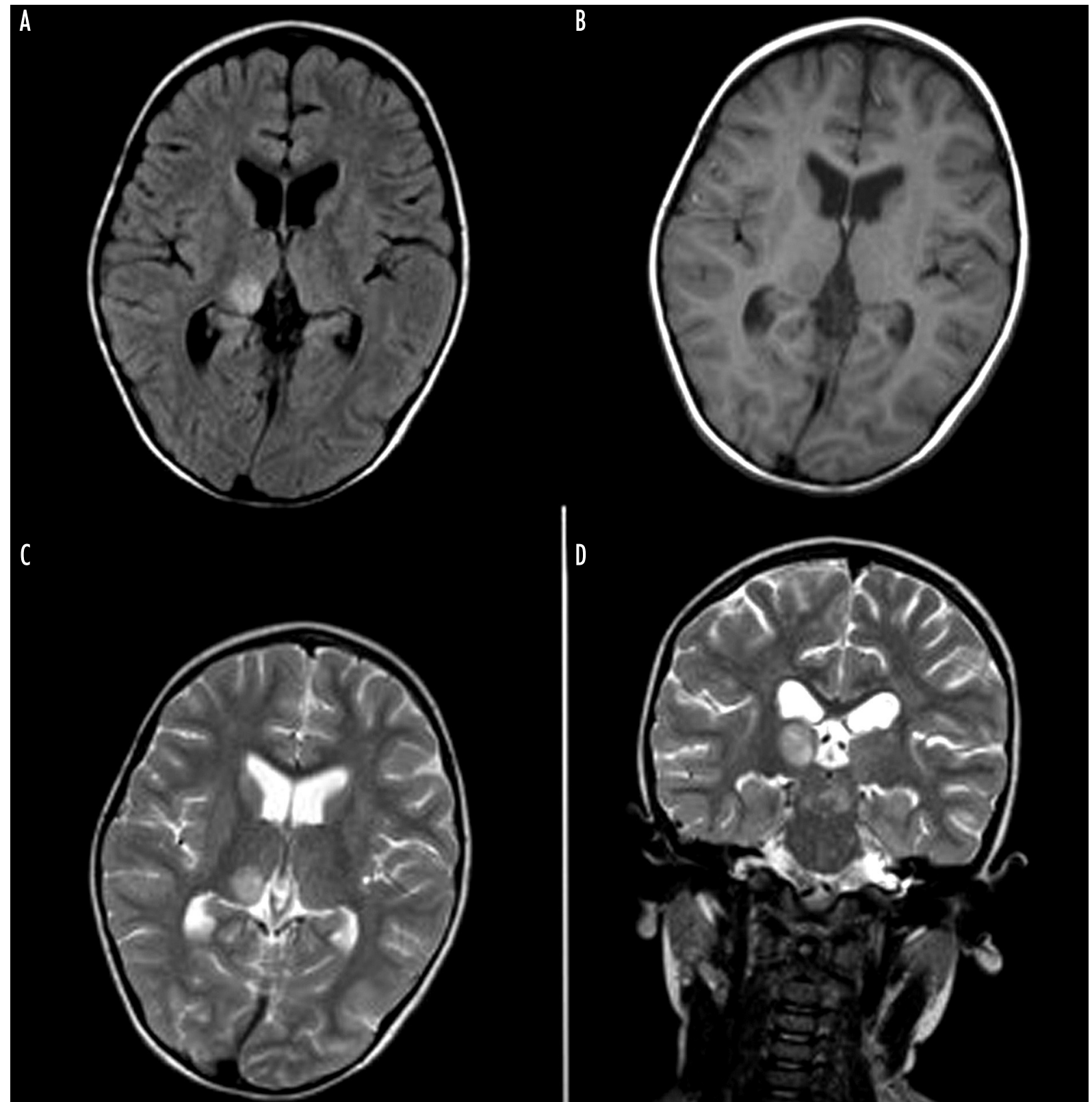

Ryc. 2. Rezonans magnetyczny mózgu dziewczynki (przypadek 2.) - ognisko w prawym wzgórzu: w projekcii poprzecznej - w sekwencii FLAIR (A); w obrazie T1-zależnym (B); w obrazie T2-zależnym (C); w projekcii czołowej, w obrazie T2-zależnym (D)

Fig. 2. Brain MRI of the girl (case 2) - abnormalities in the right thalamus: in axial image - FLAIR sequence (A), in T7-weighted image (B); in T2-weighted image (C); in frontal T2-weighted image (D)

nia biochemiczne (bilirubina, AST, ALT, mocznik, kreatynina, glukoza, lipaza, amoniak, jonogram, równowaga kwasowo-zasadowa, koagulogram, badanie ogólne moczu) wypadły prawidłowo. Badania mikrobiologiczne wykluczyły obecność bakterii w moczu, kale i krwi, natomiast badanie radiologiczne klatki piersiowej uwidoczniło zagęszczenia śródmiąższowe w przyśrodko- wych częściach płuc. Rozpoczęto dożylna antybiotykoterapię, pomimo której w 3. dobie leczenia stan dziecka znacznie się pogorszył. Wystąpiły zaburzenia świadomości, sztywność karku, a w badaniach laboratoryjnych wzrost leukocytozy do 45 tys./ $\mu$ l i 10-krotne zwiększenie stężenia CRP. Z uwagi na podejrzenie ZOMR wykonano nakłucie lędźwiowe, uzyskując PMR o nie- 
specyficznych cechach (cytoza: 203 komórki w $\mu$, stężenie białka: $54 \mathrm{mg} / \mathrm{dl}$, stężenie glukozy: $62 \mathrm{mg} / \mathrm{dl}$ ). Metodami serologicznymi wykluczono toksoplazmozę, boreliozę, zakażenie Chlamydia pneumoniae, stwierdzono natomiast obecność przeciwciał przeciwko Mycoplasma pneumoniae w klasie IgM. Posiew PMR nie wykazał obecności bakterii, ale stwierdzono trzykrotnie zwiększone stężenie immunoglobulin klasy G. W leczeniu stosowano cefalosporyny z aminoglikozydami, kortykosteroidy, immunoglobuliny i acyklowir, uzyskując po 10 dobach leczenia normalizację stanu neurologicznego oraz wykładników ostrej fazy. W 3. dobie po odstawieniu kortykosteroidów nastąpiła całkowita utrata świadomości, obserwowano sztywność karku, oczopląs poziomy i zwrot gałek ocznych w prawo, krótkotrwałe drgawki oraz spastyczność w obrębie kończyny dolnej prawej. Odnotowano ponowny wzrost leukocytozy do 30 tys./ $\mu$ l, przy prawidłowym stężeniu CRP. Wykonano kolejne badanie PMR, które wykazało małą cytozę (3 kom./ $\mu \mathrm{l}$ ), stężenie białka i glukozy w normie, nie stwierdzono również zmian w tomografii komputerowej głowy. Przez 3 dni dziewczynka wymagała wentylacji zastępczej i leczenia objawów moczówki prostej. W kolejnych dobach stan dziecka poprawiał się, choć utrzymywało się obniżone napięcie mięśniowe oraz wzmożone odruchy głębokie z przewaga po stronie prawej. W badaniu EEG czynność podstawową stanowiły nieregularne fale wolne 2,5-5 Hz o amplitudzie do $200 \mu \mathrm{V}$. Zapis wykazywał zmiany uogólnione znacznego stopnia z przewagą w odprowadzeniach lewostronnych. Wobec niejasnego obrazu klinicznego i utrzymywania się stanów gorączkowych wykonano RM głowy, w którym wykazano obecność trzech owalnych, nieostro odgraniczonych zmian o objętości 2,6, 1,32 oraz 1,32 $\mathrm{cm}^{3}$, kolejno: we wzgórzu prawym, w lewobocznej części nakrywki śródmózgowia i pokrywy śródmózgowia oraz w jądrze soczewkowatym lewym, które ulegały wzmocnieniu po podaniu kontrastu (ryc. 2.).

W leczeniu zastosowano erytromycyne, cyprofloksacynę, acyklowir, deksametazon oraz duże dawki immunoglobulin. Wykluczono zakażenie HBV, HCV, CMV, EBV, RSV, enterowirusami, Chlamydia pneumoniae i Chlamydia trachomatis. Po 4 tygodniach terapii (od momentu całkowitej utraty świadomości) stan dziewczynki znacznie się poprawił, nastąpiła normalizacja wykładników stanu zapalnego. Badanie neurologiczne wykluczyło obecność objawów ogniskowych, natomiast w zapisie EEG, wprawdzie o mniejszym nasileniu niż poprzednio, nadal utrzymywały się uogólnione zmiany, $\mathrm{z}$ przewagą $\mathrm{w}$ okolicy potylicy $\mathrm{i}$ tendencją do napado- wości. Dziewczynkę wypisano do domu w pełnym logicznym kontakcie słownym. Analiza odporności humoralnej i komórkowej wykonana w dniu wypisu wykazała niedobór limfocytów T, pobudzenie komórek NK i limfocytów B oraz zwiększone stężenie gammaglobulin. Dziecko pozostawało pod obserwacją przez kilka miesięcy. Badanie RM głowy wykonane po 4 miesiącach nie wykazało jakichkolwiek odchyleń od stanu prawidłowego. Nadal rejestrowano znacznego stopnia zmiany patologiczne w zapisie EEG w postaci nieregularnych fal wolnych o częstotliwości średnio 3-4 Hz i wysokonapięciowych z pojedynczymi falami ostrymi. W badaniu neurologicznym nie stwierdzano odchyleń, rodzice zgłaszali jedynie chwiejność emocjonalną u dziecka.

\section{Omówienie}

Ostre rozsiane zapalenie mózgu i rdzenia wraz z zapaleniem nerwu wzrokowego i poprzecznym zapaleniem rdzenia należą do nabytych zespołów demielinizacji. Choroba jest niezwykle rzadko rozpoznawana i bardzo trudna w różnicowaniu ze SR, zwłaszcza że ADEM i SR mogą następować po sobie. Częstość schorzeń demielinizacyjnych u dzieci w Niemczech szacuje się na 50 przypadków/rok [10], a w Kanadzie na 0,9 przypadku/100 tys. mieszkańców [11]. Ostre rozsiane zapalenie mózgu i rdzenia występuje częściej u dzieci i młodzieży niż u dorosłych, niemniej jednak u dzieci do 16. roku życia pięciokrotne częściej rozpoznaje się SR niż ADEM. W grupie dzieci do 16. roku życia większość, bo $72 \%$, przypadków choroby rozpoznawanych jest przed ukończeniem 10. roku życia. W Polsce nie ma danych na temat częstości nabytych zespołów demielinizacyjnych u dzieci.

Z piśmiennictwa wynika, że zwykle nie udaje się zidentyfikować bezpośredniego czynnika etiologicznego ADEM. Wiadomo, że często występuje w związku czasowym i prawdopodobnie przyczynowym $z$ chorobami wirusowymi, takimi jak: odra, ospa wietrzna, różyczka, opryszczka, świnka, mononukleoza, cytomegalia, grypa; zakażeniami bakteryjnymi (paciorkowcem grupy A i B, gruźlicą, mykoplazmą, brucelozą), jak również może wystąpić po szczepieniach ochronnych (przeciwko: wściekliźnie, ospie wietrznej, grypie, odrze, zapaleniu wątroby typu A, zółtej febrze [12]), rzadziej po podaniu surowicy przeciwtężcowej lub po ukąszeniu przez owady. U 50\% chorych w wywiadzie odnotowuje się przebyte niecharakterystyczne zakażenia górnych dróg oddechowych [13]. Istnieją pojedyncze doniesie- 
nia o przypadkach ADEM po bakteryjnym ZOMR wywołanym przez Haemophilus influenzae [14].

Objawy ADEM pojawiają się zwykle od 1 do 3 tygodni po przebyciu zakażenia lub po szczepieniu czy przetoczeniu surowicy i rozpoczynają się ostrą, wysoką gorączką, bólami głowy, wymiotami i podrażnieniem opon mózgowo-rdzeniowych. Kolejno pojawiają się: zaburzenia nastroju, senność prowadząca do śpiączki o różnym nasileniu, drgawki oraz ogniskowe objawy neurologiczne: niedowłady, zaburzenia mowy, zespoły pozapiramidowe - drżenie, pląsawica, dystonia. Zmiany w PMR w przebiegu ADEM najczęściej są mało charakterystyczne, zwykle obserwuje się limfocytarną pleocytozę do $10 \mathrm{kom} . / \mu \mathrm{l}$, stężenie białka do $100 \mathrm{mg} / \mathrm{dl}$, zwiększenie stężenia $\operatorname{Ig} G$ oraz zwiększenie stężenia białka zasadowego mieliny jako wyraz rozpadu mieliny.

Fujikui i wsp. ocenili przebieg jałowego ZOMR u 25 chorych w wieku 16-55 lat. U 5 z nich ADEM rozwinęło się po 5-19 dobach od pierwszych objawów ZOMR. Szukano czynników predysponujących do rozwoju ADEM. Nie stwierdzono różnic istotnych statystycznie odnośnie do wieku i płci chorych oraz w wynikach badań laboratoryjnych, takich jak: leukocytoza, CRP, stężenie potasu w surowicy, pleocytoza i stężenie białka w PMR. Różnica statystyczna dotyczyła natremii [w grupie rozwijającej ADEM średnio 130,4 mmol/ $( \pm 5,4)$, w grupie bez powikłania średnio $139,1 \mathrm{mmol} / \mathrm{l}( \pm 2,4)]$ i intensywności gorączki [w grupie rozwijającej ADEM średnio $39,6^{\circ} \mathrm{C}\left(39,4-40,8^{\circ} \mathrm{C}\right)$, w grupie bez powikłania średnio $\left.37,7^{\circ} \mathrm{C}\left(37,2-39,6^{\circ} \mathrm{C}\right)\right]$. Cztery piąte chorych na jałowe ZOMR, którzy rozwinęli ADEM, miało stężenie sodu $<135 \mathrm{mmol} / \mathrm{l}$ i wszyscy gorączkowali więcej niż 5 dni powyżej $38^{\circ} \mathrm{C}$. Autorzy sugerują, że pacjenci z hiponatremią w przebiegu jałowego ZOMR powinni być poddani wnikliwej obserwacji w czasie [15].

Przedstawione w pracy przypadki ADEM byly poprzedzone rozpoznaniem jałowego ZOMR występowały wszystkie typowe objawy choroby. Nie można jednoznacznie ustalić, czy zakażenie Mycoplasma pneumoniae u dziewczynki i zakażenie HSV u chłopca były czynnikami etiologicznymi choroby czy wspótistniejącym zakażeniem. Dzieci gorączkowały powyżej $39^{\circ} \mathrm{C}$ przez kilka dni, u chłopca nie obserwowano zaburzeń elektrolitowych, dziewczynka prezentowała objawy moczówki prostej w fazie rozpoznania ADEM. Autorzy sądzą, że przedstawione przez nich przypadki mieszczą się w kategoriach rozpoznania ADEM rozwijającego się w wyniku patologicznej odpowiedzi immunologicznej wywołanej zakażeniem, w opisanych przypadkach ZOMR, o czym świadczy dwufazowy przebieg choroby. Pierwszy etap - zakażenie manifestujące się gorączką, leukocytozą, zmianami w PMR, następnie okres poprawy, po którym pojawiły się po ok. 10 dniach rozsiane objawy uszkodzenia układu nerwowego.

Badanie EEG w ADEM wykazuje zwolnienie ryt$\mathrm{mu}$ podstawowego $\mathrm{z}$ wysokim woltażem o nasileniu zmian proporcjonalnym do ciężkości choroby. Podobne zmiany w zapisie obserwowano w opisanych przypadkach. W doniesieniach innych autorów TK mózgu wykazywało hipodensyjne zmiany w istocie białej, ulegające zwykle wzmocnieniu po podaniu kontrastu. W przypadku opisanej dziewczynki nie obserwowano zmian w istocie białej w badaniu TK.

Diagnostyka różnicowa objawów przypominających ADEM obejmuje bakteryjne i wirusowe ZOMR, opryszczkowe zapalenie mózgu, uraz głowy, krwiak mózgu, zatrucie lekami, poprzeczne zapalenie rdzenia, guz rdzenia kręgowego oraz zespół Guillaina-Barrégo. Najwięcej kontrowersji budzi różnicowanie pomiędzy SR i ADEM, a szczególnie z wielofazowym ADEM, gdzie nawrót choroby następuje krótko po odstawieniu kortykosteroidów lub po kolejnym zakażeniu, nawet po pełnym lub częściowym ustąpieniu objawów pierwszego rzutu [16]. Ostre rozsiane zapalenie mózgu i rdzenia prawie zawsze charakteryzuje się: wieloogniskowością pierwszych objawów, cechami encefalopatii, leukocytozą, rzadko występowaniem kolejnych rzutów, najczęściej brakiem lub szybkim zanikaniem prążków oligoklonalnych w PMR. W obrazach RM w przebiegu ADEM zwykle obserwuje się duże i rozlane (powyżej $2 \mathrm{~cm}$ ) zmiany o zatartych granicach, zlokalizowane w okolicy jąder podstawy, niekiedy hiperintensywne w sekwencjach T2-zależnych i FLAIR, które często ulegają wzmocnieniu kontrastowemu w ostrej i podostrej fazie choroby [17]. Z kolei w SR bardzo rzadko obserwuje się wieloogniskowość pierwszych objawów, cechy encefalopatii i leukocytozę, zawsze występują kolejne rzuty choroby, prążki oligoklonalne w PMR są obecne bardzo często i nie zanikają w kolejnych badaniach. W przebiegu SR w badaniach RM występują „plastyczne" zmiany, o wyraźnych granicach, najczęściej zlokalizowane okołokomorowo, w wieńcu promienistym, pniu mózgu i okolicy IV komory; rzadko zanikają w obrazach T2-zależnych, a wzmocnieniu po podaniu kontrastu ulegają tylko w ostrej fazie choroby [18]. Zmiany opisywane w przedstawionych przypadkach zdecydowanie przemawiają za rozpoznaniem ADEM. Badacze z Holandii obserwowali 117 dzieci z ADEM - u 54 pacjentów występowały pojedyncze ogniska 
demielinizacji, a u 63 zmiany wieloogniskowe. Nawrót choroby spełniający kryteria SR stwierdzano statystycznie częściej w grupie z pojedynczym ogniskiem w pierwotnym badaniu RM głowy [19]. Opisywani w niniejszej pracy pacjenci prezentowali zmiany wieloogniskowe w ostrym okresie choroby, w trakcie 5-miesięcznej obserwacji nie odnotowano $u$ nich nawrotu choroby.

Doniesienia pochodzące z ostatnich lat podważają pogląd, że obecność jednostronnego, pozagałkowego zapalenia nerwu wzrokowego jest cechą charakterystyczną dla SR. Chirapapaisan i wsp. wykazali, że zapalenie nerwu wzrokowego jest zwykle obustronne, występuje równie często u pacjentów obu płci i częściej obserwowane jest w ADEM niż w SR [20]. Kolus stwierdził zapalenie nerwu wzrokowego w 6 na 10 przypadków ADEM, gdzie $90 \%$ zapaleń dotyczyło obu nerwów wzrokowych [21]. W badaniach własnych spośród dwojga opisanych dzieci chłopiec przebył obustronne zapalenie nerwu wzrokowego, które ustąpiło po 4 miesiącach obserwacji.

$\mathrm{W}$ piśmiennictwie nie ma badań $\mathrm{z}$ randomizacją oceniających skuteczność różnych metod leczenia stosowanych u chorych na ADEM. Najbardziej popularna jest terapia kortykosteroidami, która zmniejsza obrzęk mózgu i proces zapalny, przepuszczalność bariery krew-mózg oraz przenikanie białek osocza i aktywnych immunologicznie komórek do OUN. Ponadto zalecane jest stosowanie metyloprednizolonu we wlewach przez 5 dni, natomiast dyskusyjne jest podawanie kortykosteroidów doustnych w kolejnych dniach terapii. Lekiem drugiego rzutu są immunoglobuliny zalecane w dawce $0,4-0,5 \mathrm{~g} / \mathrm{kg}$ m.c./dobę przez 5 dni. W przypadkach opornych na steroidoterapię i immunoterapię lub w przypadkach o bardzo ciężkim przebiegu polecana jest plazmafereza, która w liczbie 5-7-10 zabiegów prowadzi zwykle do wyzdrowienia lub znacznej poprawy [22-24]. W leczeniu chorych na ADEM bardzo ważne jest postępowanie objawowe, niekiedy może być konieczna intubacja, zastosowanie oddechu kontrolowanego, wyrównywanie zaburzeń wodno-elektrolitowych i kwasowo-zasadowych, leczenie przeciwdrgawkowe i przeciwbakteryjne. W przypadku omawianego chłopca wyleczenie uzyskano po steroidoterapii, natomiast dziewczynka otrzymywała zarówno kortykosteroidy, jak i immunoglobuliny.

Przebieg choroby, pomimo niepokojących objawów początkowych i dużych zmian w badaniach obrazowych głowy, najczęściej jest pomyślny, zwykle następuje pełne wyzdrowienie, chociaż mogą utrzymywać się zaburzenia mowy, zachowania, napady padaczkowe. Tajwańscy badacze wśród 20 dzieci chorych na ADEM, u 11 opisali pełne wyzdrowienie, jeden pacjent zmarł, u 5 obserwowano odchylenia w badaniu neurologicznym, u 3 po dwóch latach obserwacji rozpoznano SR [25]. Następstwem ADEM u omawianej dziewczynki są zaburzenia nastroju, u chłopca nie obserwowano odległych następstw choroby.

\section{Podsumowanie}

Rozpoznanie ADEM z uwagi na rzadkie występowanie i brak znamiennych wskaźników laboratoryjnych choroby należy do bardzo trudnych i nigdy nie jest pewne. Kryterium kliniczne rozpoznania stanowi obecność ostrych objawów mózgowych i/lub rdzeniowych połączonych z gorączką, pozostających w związku czasowym z zakażeniem wirusowym, bakteryjnym, szczepieniem lub przyjęciem surowicy odpornościowej. Konsekwencją ZOMR przebiegającego z wysoką, długo trwającą gorączką może być ADEM.

Szczególnie trudne jest różnicowanie u dzieci pomiędzy ADEM i ostrym SR, a potwierdzenie rozpoznania ADEM można uzyskać dopiero po wieloletniej obserwacji, zwłaszcza że SR w porównaniu z ADEM jest chorobą częściej występującą. Najbardziej pomocnym badaniem w różnicowaniu obu jednostek chorobowych jest badanie za pomocą RM.

\section{Oświadczenie}

Autorki zgłaszają brak konfliktu interesów.

\section{Piśmiennictwo}

1. Tenembaum S., Chamoles N., Fejerman N. Acute disseminated encephalomyelitis: a long-term follow-up study of 84 pediatric patients. Neurology 2002; 59: 1224-1231.

2. Rust R.S. Multiple sclerosis, acute disseminated encephalomyelitis and related conditions. Semin Pediatr Neurol 2000; 7 : 66-90.

3. Tselis A., Lisak R. Acute disseminated encephalomyelitis. W: Antel J., Birnbaum G., Hartung H.-P., Vincent A. [red.]. Clinical neuroimmunology. Oxford University Press, Oxford 2005, ss. 147-17.

4. Caldemeyer K.S., Smith R.R., Harris T.M. i wsp. MRI in acute disseminated encephalomyelitis. Neuroradiology 1994; 36: 216-220.

5. Miller D.H., Robb S.A., Ormerod I.E. i wsp. Magnetic resonance imaging of inflammatory and demyelinating whitematter diseases of childhood. Dev Med Child Neurol 1990; 32: 97-107. 
6. Pasternak J.F., DeVivo D.C., Pewnaky A. i wsp. Steroid responsive encephalomyelitis in childhood. Neurology 1999; 14: 198-201.

7. Straub J., Chofflon M., Delavalle J. Early high-dose intravenous methylprednisolone in acute disseminated encephalomyelitis: a successful recovery. Neurology 1997; 49: 1145-1147.

8. Kleiman M., Brunquell P. Acute disseminated encephalomyelitis: response to intravenous immunoglobulin? J Child Neurol 1995; 10: 481-483

9. Kanter D.S., Horensky D., Sperling R.A. i wsp. Plasmapheresis in fulminant acute disseminated encephalomyelitis. Neurology 1995; 45: 824-827.

10. Pohl D., Hennemuth I., von Kries R. i wsp. Paediatric multiple sclerosis and acute disseminated encephalomyelitis in Germany: results of a nationwide survey. Eur J Pediatr 2007; 166: 405-412.

11. Banwell B., Kennedy J., Sadovnick D. i wsp. Incidence of acquired demyelination of the CNS in Canadian children. Neurology 2009; 72: 232-239.

12. Alehan F.K., Kahveci S., Uslu Y. i wsp. Acute disseminated encephalomyelitis associated with hepatitis A virus infection. Ann Trop Paediatr 2004; 24: 141-144.

13. Lin C.H., Jeng J.S., Hsieh S.T. i wsp. Acute disseminated encephalomyelitis: a follow-up study in Taiwan. $J$ Neurol Neurosurg Psychiatry 2007; 78: 162-167.

14. Beleza P., Ribeiro M., Pereira J. i wsp. Probable acute disseminated encephalomyelitis due to Haemophilus influenzae meningitis. Dev Med Child Neurol 2008; 50: 388-391.

15. Fujiki F., Tsuboi Y., Hori T. i wsp. Aseptic meningitis as initial presentation of acute disseminated encephalomyelitis. J Neurol Sci 2008; 272: 129-131.

16. Dale R.C., Branson J.A. Acute disseminated encephalomyelitis or multiple sclerosis: can the initial presentation help in establishing a correct diagnosis? Arch Dis Child 2005; 90: 636-639.

17. Thomas G.S., Hussain I.H. Acute disseminated encephalomyelitis: a report of six cases. Med J Malaysia 2004; 59: 342-351.

18. Kotulska K., Jóźwiak S., Jurkiewicz E. i wsp. ADEM czy SM - trudności diagnostyczne. Neurologica 2005; 4: 55-58.

19. Neuteboom R.F., Boon M., Catsman Berrevoets C.E. i wsp. Prognostic factors after a first attack of inflammatory CNS demyelination in children. Neurology 2008; 71: 967-973

20. Chirapapaisan N., Borchert M.S. Pediatric optic neuritis. J Med Assoc Thai 2008; 91: 323-330.

21. Kotlus B.S., Slavin M.L., Guthrie D.S. i wsp. Ophthalmologic manifestations in pediatric patients with acute disseminated encephalomyelitis. J AAPOS 2005; 9: 179-183.

22. Shinozaki K., Oda S., Sadahiro T. i wsp. A case report of plasmapheresis in the treatment of acute disseminated encephalomyelitis. Ther Apher Dial 2008; 12: 401-405.

23. Khurana D.S., Melvin J.J., Kothare S.V. i wsp. Acute disseminated encephalomyelitis in children: discordant neurologic and neuroimaging abnormalities and response to plasmapheresis. Pediatrics 2005; 116: 431-436.

24. Morimatsu M. Recurrent ADEM or MS? Intern Med 2004; 43: 647-648

25. Weng W.C., Peng S.S., Lee W.T. i wsp. Acute disseminated encephalomyelitis in children: one medical center experience. Acta Paediatr Taiwan 2006; 47: 67-71. 